\title{
Enthusiasm of Actors Within the Groundnut Value Chain Sharing Impact Stories in Uganda
}

\subsection{Women's Battle for Financial Independence: How Women Are Using Groundnut to Attain Financial Stability in Uganda}

The role of women in traditional African homes is often considered subordinate than that of men. Women in most cases are expected to look after the household and the children and ensure food security while men, on the other hand, are tasked with ensuring financial security. In Uganda, women contribute to $53 \%$ agricultural labor force; this is because they have limited access to land and thus resort to offering labor to farm owners. Tropical Legumes projects has strived to empower women through creating awareness and sensitizations to women groups in various parts of the country (Fig. 4.1).

Purlonyo Women Group is among farmer groups that have benefited from the TL projects. Rather than staying at home and waiting to be financially supported, the women have settled on self-empowerment. Ms. Leonora Okidi founded Purlonyo Women Group with an aim of inspiring women to uplift themselves.

The group consists of 35 groundnut producers from Pader District, nine are men despite being a women group. Before joining the Tropical Legumes projects the group produced old groundnut varieties solely for household consumption.

\footnotetext{
We started out as farm laborers where we would get hired by community members to till land during planting and weeding season. We also planted groundnut for grain but our earnings from the work were insufficient and we needed to look for diverse ways to sustain our needs.
}

Encouraged by the extension officers and project staff, the group members embarked on a journey of farming improved groundnut varieties such as Serenut, 5, 8 , and 9 which they received through Green Globe, an NGO that works closely with the Tropical Legumes projects. Ms. Leonora Okidi, the group's chairperson, volunteered 10 acres of her land to the group members for groundnut production. Since 


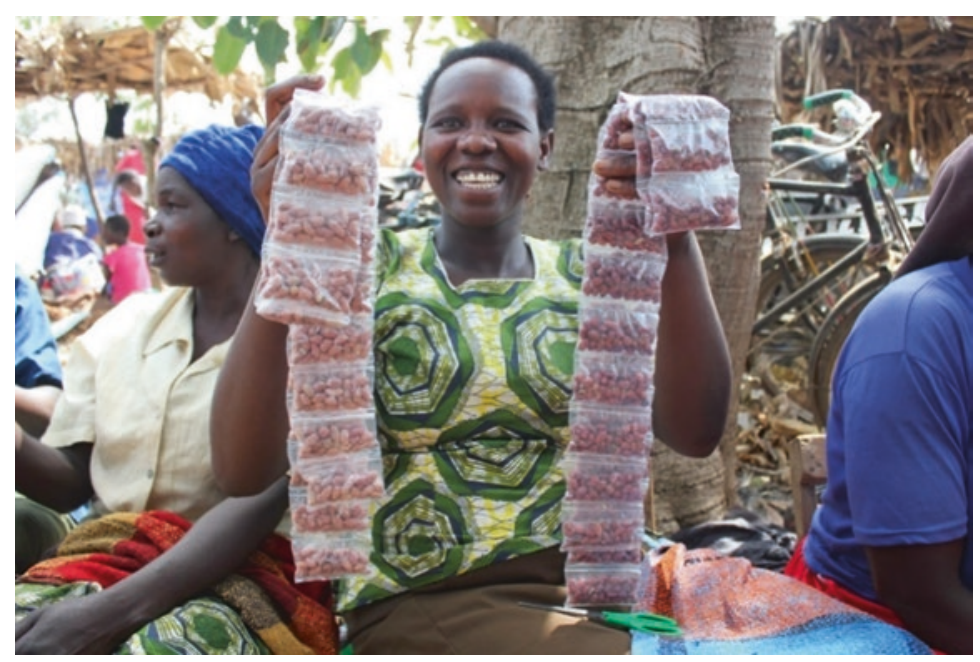

Fig. 4.1 Ms. Apiyo Hellen, a groundnut trader, shows off her roasted groundnut at Arapai market in Soroti, Uganda (Photo: Manyasa E)

joining the TL projects 2 years ago, Purlonyo women group has benefited immensely, besides the improved variety seed, they have been trained thoroughly on production and have been linked to markets for their produce.

The differences between the old varieties and the improved varieties of groundnut are immense according to Leonora. The old varieties, despite having a higher oil content which makes them more desirable, are less resistant to drought conditions, pests, and diseases and are low yielding. The market demand for the improved varieties, moreover, is higher than that of the old varieties. In 2016, for instance, a sack of unshelled groundnut of improved groundnut was 120,000UGX but in 2017 the price went higher to 140,000 UGX (1US\$ is about 3700UGX at the time of data collection).

When we started off, we were a bit skeptical on who would buy our produce. Two years into the business, we have links with seed companies and organizations like the Lutheran World Foundation who have promised to buy seed from us after the harvesting season as we produce quality seed. We have also benefited from workshops and demonstrations organized by the TL projects and thus expanded our networks, the opportunities we have received surpassed our expectations.

Since joining the project 3 years ago, the group members' lives have been transformed significantly. Most of the members can now afford to keep their children in school with the profit made from the groundnut sales. Leonora for instance no longer relies on her estranged husband for any form of financial support as she makes enough to send her children to school and cater for all their needs.

Ms. Ademun Loy is also among the many women that have benefited from Tropical Legumes projects in Uganda. Loy, a farmer and small-scale businesswoman, produces groundnut paste and roasted groundnut for sale. Her journey to 
financial independence started in 1998, when she moved to her sisters' home in Teso Inn village, Soroti District, after she parted ways with her husband. Being the sole breadwinner, her income from her cassava business could not sustain the needs of her two children and herself. Her sister was a groundnut dealer; she roasted groundnut and made groundnut paste which she hawked in Soroti town and sell to neighbors in her home village. "I mentioned to my sister that I needed an extra source of income since my estranged husband wasn't helping with raising the children, I also needed to get a place of my own as my sister's house was small for both our families," she added.

Loy's sister trained her on proper preparation of the groundnut for sale, and in 2000 , with a capital of 50,000UGX, she started her own business. She utilized Erudu, a white local variety, to make the roasted groundnut and Serenut 2 for making groundnut paste. When she started off, she sold the groundnut to neighbors and hawked some around town, but she currently supplies supermarkets and local shops in Soroti with her products. She makes approximately 44,000UGX a day from $6 \mathrm{~kg}$ of groundnut.

In 2016, she acquired home-saved seed from farmers in her village and she planted it on her one acre of land. That season, the crop was adversely affected by Rosette diseases and she only managed to harvest $126 \mathrm{~kg}$ of unshelled groundnut. "The variety I used is an old variety and it is not disease resilient and that is why it was severely affected, but now with links to the research institute who contacted me after they saw my products on the supermarket shelf, I am sure that I will receive better quality seeds for my next planting season," said Loy. "I am in contact with the research team at Serere and so far, I have received material with information on the different varieties of groundnut which I find very useful," she added.

From the profit made from her groundnut business, Loy (Fig. 4.2) has been able to buy six goats which she rears for milk, she has rented a house for her children and herself, has been able to pay school fees for the children, and is able to also support some of her relatives.

Fig. 4.2 Ms. Ademun Loy, a happy farmer and small-scale businesswoman, Soroti, Uganda (Photo: Manyasa E)

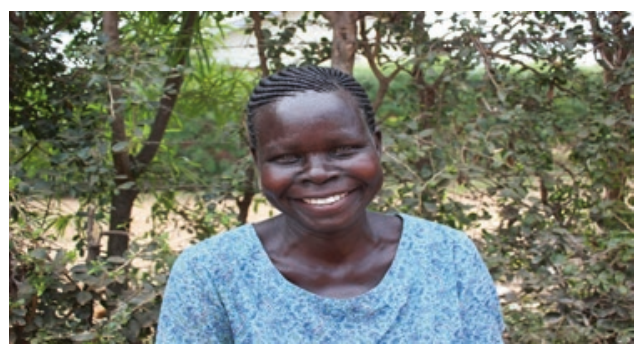




\subsection{Against All Odds: Farmers Actualizing Their Dreams with New Groundnut Varieties}

The Teso war deterred Mr. Martin Ocung's dream of completing high school and subjected him to poverty after the death of his two parents. He dropped out of Primary 7 due to lack of school fees, but as fate would have it, he met Dr. David Kalule, a groundnut breeder at NaSARRI and that was the beginning of Martin's journey with improved groundnut varieties. The 30-year-old Martin (Fig. 4.3 and 4.4) hails from Okulonyo village in Serere District, Eastern Uganda. He started planting the improved variety of groundnut in 2014.

Martin is different from the other farmers in his village as he works closely with the NaSARRI team to produce both breeder and foundation seed. He received lines from the research institute which were tried out in his farm. Martin also received additional training from the research team on how to properly manage his crop in the farm. According to Martin, the information disseminated to him has tremendously changed his life. "I am wiser than I was 5 years ago, the new varieties I received from NaSARRI, perform much better than the old varieties I used to farm before," noted Martin. The seed class he produces has a higher market value than the other seed classes; this sees Martin making great profit.

The new varieties that Martin farms include Serenut 8 and 11. He works closely with NaSARRI on multiplying some new varieties that would be released in 2018 . According to Martin, being involved in the Participatory Variety Selection is beneficial to him as he has first-hand information on the new varieties, and he can comfortably select the variety that has desirable characteristics.

The climate has been very unpredictable in the last couple of seasons, so whenever I'm selecting a variety, I have to ensure that it is drought hardy, I go for varieties that are high yielding and pest tolerant. The old varieties are easily attacked by diseases like Rosette which highly affects the yield at the end of the season.

Martins' life has changed since he got involved with the projects in 2013; not only has he increased groundnut production (from 1 acre in 2008 to 7 acres in 2016) he can now afford private schools for his five children and can take care of his wife's needs. In addition to that, he has bought more land; in 2005 he only had one acre of

Fig. 4.3 Mr. Martin Ocung, a farmer and former post war orphan in Serere, Uganda (Photo: Manyasa E)

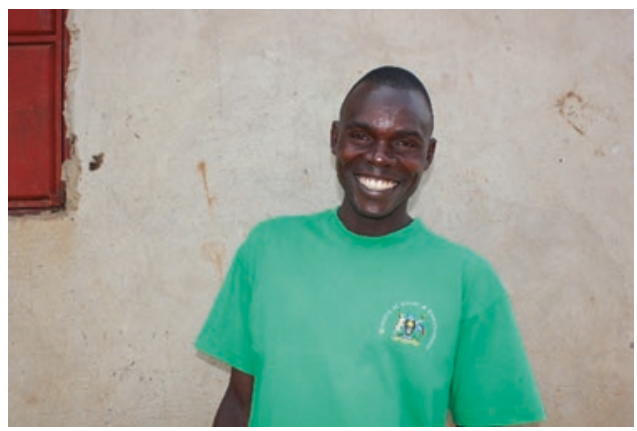


Fig. 4.4 Mr. Martin

Ocung's newly constructed guest quarters (Photo: Manyasa E)
Fig. 4.5 Mr. Geoffery Oceng with his bull bought through proceeds from improved groundnut production, Dokolo, Uganda (Photo: Manyasa E)
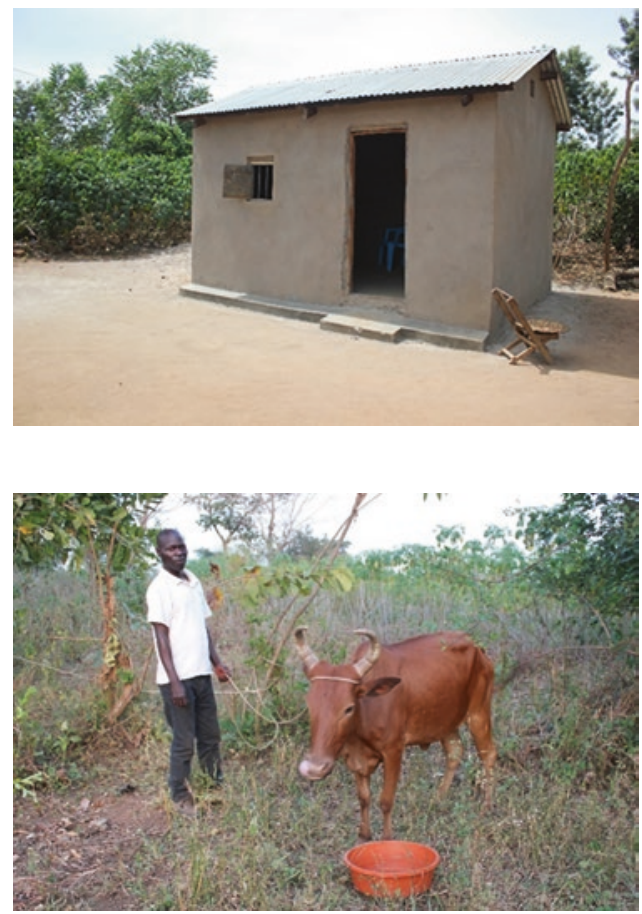

land, and from the money he accumulated from his groundnut business he bought 5 acres of land. "Before my engagement with the Tropical Legumes projects, I got very low yield, in 2008 for instance I planted 192kilos of Eruduru Red groundnut and only managed to harvest 1600kilos, the yield was very discouraging and that's when I switched to the new varieties of groundnut," added Ocung.

Martin has even greater plans from the income he will receive from his groundnut farm, he has leased out more land and he is anticipating more yield which translates to more income for his household. Martin already owns a produce business, and from the money he will receive after the next season, he plans to build a bigger storage facility for his produce.

Mr. Geoffery Oceng's story is no different from Martins. Oceng (Fig. 4.5) survived on meagre earnings from his metal fabrication job. Poverty and bad grades couldn't allow him pursue higher education. He ventured into groundnut farming where he started off with the local varieties of groundnut which were readily available to him. From one acre of land he harvested $294 \mathrm{~kg}$ of unshelled groundnut. The results of his harvest weren't pleasant, but he was determined to be a great farmer.

I faced myriad challenges before I joined the Tropical Legumes projects I had no access to foundation seed, and I relied heavily on recycled ones. I was not able to differentiate between grain and seed when I went to buy seed from the market. I had no farming skills when I started out thus, I couldn't maintain quality of seed. In addition, I did not have any links to research centers. 
Through extension officers, Oceng has been fortunate to receive trainings on good agronomic practices which he has adhered to. He received improved groundnut varieties which he has been planting.

Geoffery (Fig. 4.6) earns $80 \%$ of his income from improved varieties of groundnut. From one acre he harvests up to $1050 \mathrm{~kg}$ of unshelled groundnut. His income has tripled, and he has invested the profit earned to improve his livelihood. $\mathrm{He}$ recently constructed a permanent house, purchased cattle, and started up a cloth business for his wife in the small town of Dokolo.

\subsection{Scaling up Improved Groundnut Varieties: Tropical Legumes Revolutionized Groundnut Breeding in Uganda}

A decade ago, groundnut was considered an orphan crop in Uganda; it didn't attract funding like most cereals and legumes did, and most of the people thought it would remain a subsistence crop. The tale has however changed, and groundnut are now the most important legume after bean in Uganda. The cultivated area of the legume is estimated at nearly 260,000 ha, representing $24.6 \%$ of the total arable land in Uganda. Since Tropical Legumes began in Uganda in 2011, the groundnut breeding program has become stronger than it used to be according to Dr. David Okello, a groundnut breeder at National Semi Arid Resources Research Institute (NaSARRI) in Serere.

Dr. Okello is the only groundnut breeder in Uganda and thus the task of ensuring developing new varieties of groundnut with desirable traits is solely on him. Groundnut are cultivated largely by poor farmers; this has enabled him work one on one with the locals in scaling up production of the legume. Groundnut consumption is also very popular in every part of Uganda.

From the funds received in the 5 years of working with the Tropical Legumes projects, a couple of things stand out for the breeding program. For starters, there has been an increase in production of breeder seed (below 1 ton to currently 5 tons in 2017) which in turn has increased the amount of foundation seed (over 80 tons in 2017) being produced by farmers in the country (Fig. 4.7). Dr. Paul Anguria, an Agronomist

Fig. 4.6 Geoffery Oceng's newly constructed house in Dokolo District (Photo: Manyasa E)

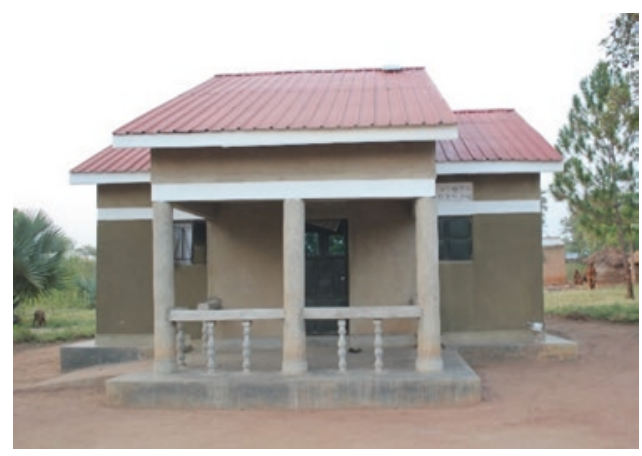



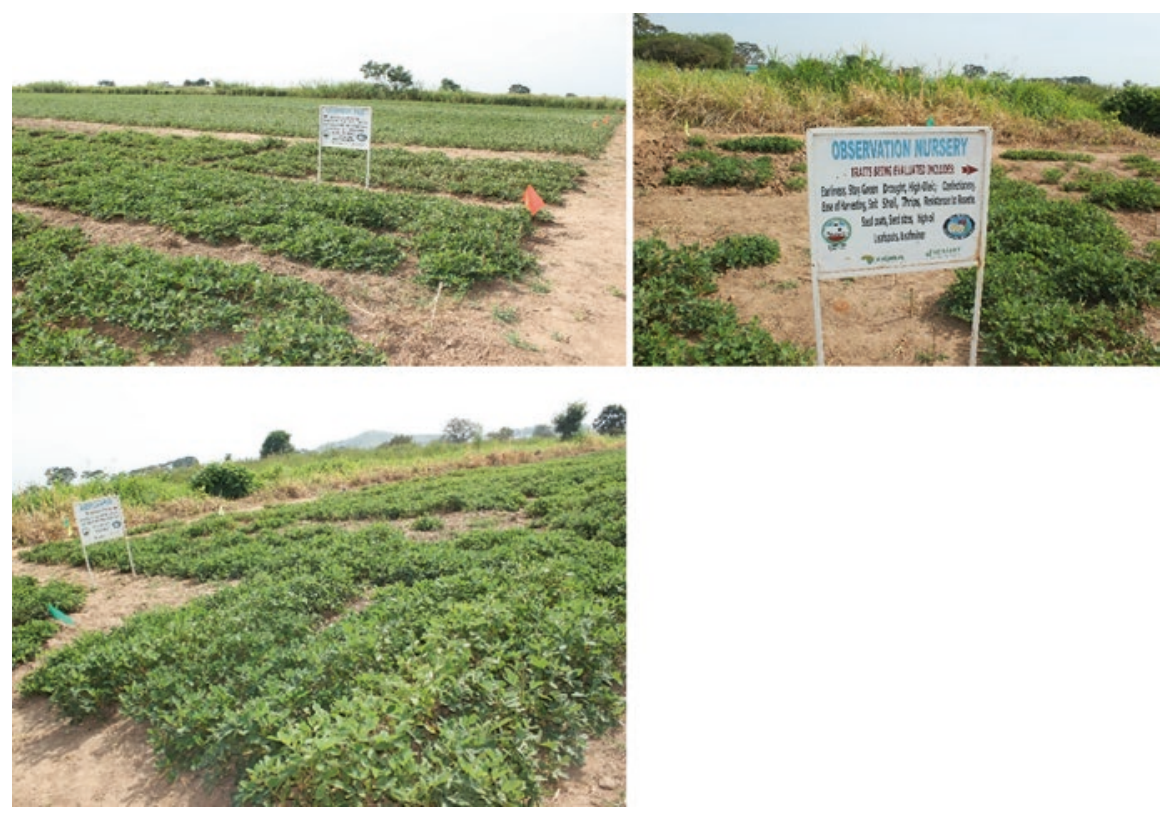

Fig. 4.7 Groundnut nursery at NaSSARI in Serere, Uganda (Photo: Manyasa E)

at NaSARRI, notes that initially farmers were missing out on the new varieties and technologies, but since they got acquainted with them production has gone up.

With support from the project, the farmers are now more informed when it comes to new varieties, diseases, maturity, types of soils and crop growth. Convincing them to take up the new varieties is however challenging as they are attached to the indigenous varieties. Through the project, the farmers have access to affordable and quality seed.

Dr. Okello and his team at NaSARRI have been able to build a regional connection with different research institutions across and beyond Africa. The Institution, for instance, receives breeding material and technical support from CGIAR centers including ICRISAT Malawi, India, and the regional office in Nairobi. Before the project, the institution could handle 120 lines and approximately 40 crosses in a year. Overtime, with funding and support from Tropical Legumes projects and other partners, the team can comfortably handle over 600 lines and more than 60 crosses in a year. The lines and varieties have been shared with National Programs across Africa (Fig. 4.8).

Participatory plant breeding: The project also accords the research team to conduct participatory plant breeding; this enables the breeder to know exactly what the farmers and processors want in a variety and from that they come up with the appropriate variety. Conducting demonstrations and PVSs had been a hurdle previously due to financial constraints, but with funding more than 40 demonstrations is conducted in a year. 
Fig. 4.8 Groundnut samples (Photo: Manyasa E)

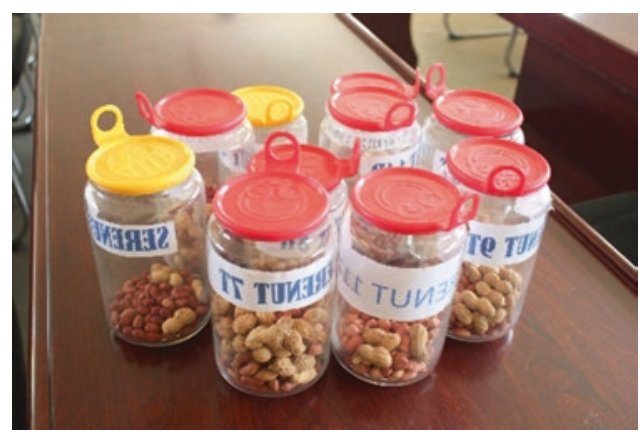

Digital data collection tool: Data collection is no longer a challenge as the researchers have shifted to digital form of data collection. The Breeding Management Systems has ensured data is not lost or distorted. Tropical Legumes contribute to $40 \%$ of the research work on groundnut at Serere. Since the project's inception, the institution with funding from the project has been able to release nine new varieties of groundnut that are early maturing and more resilient to local diseases and drought, and hope to release more varieties with desirable variety traits in the future. Dr. Anguria Paul is hopeful that once aflatoxin and storage issues are addressed, groundnut could easily overtake beans as the largest produced legume in Uganda.

Open Access This chapter is licensed under the terms of the Creative Commons Attribution 4.0 International License (http://creativecommons.org/licenses/by/4.0/), which permits use, sharing, adaptation, distribution and reproduction in any medium or format, as long as you give appropriate credit to the original author(s) and the source, provide a link to the Creative Commons licence and indicate if changes were made.

The images or other third party material in this chapter are included in the chapter's Creative Commons licence, unless indicated otherwise in a credit line to the material. If material is not included in the chapter's Creative Commons licence and your intended use is not permitted by statutory regulation or exceeds the permitted use, you will need to obtain permission directly from the copyright holder.

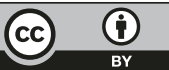

